\title{
Artikel
}

\section{Fusietoetsing in de zorg: een terug- en vooruitblik}

\author{
Marco Varkevisser en Erik Schut*
}

Het fusietoezicht in de zorg staat al jaren ter discussie. Dit artikel gaat in op (1) de invoering van en ervaringen met de zorgspecifieke fusietoets en (2) de ontwikkelingen in het mededingingstoezicht op zorgfusies. Bij de zorgspecifieke fusietoets valt te betwijfelen of de voordelen opwegen tegen de nadelen. Dit pleit voor een herbezinning op nut en noodzaak van deze toets. Het mededingingstoezicht op zorgfusies is lange tijd te toegeeflijk geweest. Er lijkt sprake van een kentering, maar deze komt te laat om in sommige zorgsectoren en regio's dominante machtposities te voorkomen. Vandaar dat sterker optreden tegen machtsposities geboden is.

\section{Inleiding}

Alweer bijna negen jaar geleden schreven wij in dit tijdschrift een kritisch artikel over het toenmalige toezicht op zorgfusies en de voorgenomen invoering van een extra zorgspecifieke fusietoets. Onze belangrijkste conclusies van destijds kunnen als volgt worden samengevat: ${ }^{1}$

'De effectiviteit van het huidige toezicht op zorgfusies staat volop ter discussie. Het kabinetsvoornemen om [voorafgaand aan de toets op grond van de Mededingingswet] een zorgspecifieke fusietoets in te voe-

* Prof. dr. M. Varkevisser is als hoogleraar verbonden aan Erasmus School of Health Policy \& Management (ESHPM) van de Erasmus Universiteit Rotterdam. Prof. dr. F.T. Schut is als hoogleraar verbonden aan Erasmus School of Health Policy \& Management (ESHPM) van de Erasmus Universiteit Rotterdam.

1. M. Varkevisser \& F.T. Schut, 'Zorgspecifieke fusietoets is overbodig en ongewenst', TVT 2011, afl. 1, p. 33-41. ren is echter overbodig en ongewenst. Er zijn vooralsnog namelijk geen criteria waarmee kwaliteitsverlagende effecten van schaalvergroting vooraf kunnen worden vastgesteld. (...) Voor het toezicht op zorgfusies belooft 2011 een spannend jaar te worden. Het afgelopen jaar heeft de NMa, samen met de NZa, bij drie voorgenomen zorgfusies haar tanden laten zien. De komende periode moet duidelijk worden of de mededingingsautoriteit op het gebied van zorgfusies, indien nodig, ook durft te bijten.'

In aanloop naar het tweede lustrum van dit tijdschrift heeft de redactie ons gevraagd om met de kennis van nu nogmaals naar dit onderwerp te kijken. Met dit artikel, waarin wij terug- en vooruitblikken, gaan wij graag op deze uitnodiging in. In de terugblik zullen we achtereenvolgens de ervaringen met de zorgspecifieke fusietoets en het mededingingstoezicht op zorgfusies bespreken. Vervolgens zullen we in de vooruitblik op basis van deze ervaringen voor beide vormen van fusietoezicht lessen trekken voor de toekomst.

\section{Terugblik: invoering zorgspecifieke fusietoets}

Zuiver procedurele toets

Om te zorgen dat de overheid 'haar verantwoordelijkheid kan nemen wanneer de kwaliteit of de bereikbaarheid van de zorg in gevaar komt als gevolg van schaalvergroting, ${ }^{2}$ is op 1 januari 2014 de zorgspecifieke fusie- 
toets in werking getreden. ${ }^{3}$ Sindsdien is het op grond van artikel 49a Wet marktordening gezondheidszorg (Wmg) voor zorgaanbieders verboden 'een concentratie tot stand te brengen, zonder daaraan voorafgaande goedkeuring van de zorgautoriteit. ${ }^{4}$ Concreet komt het erop neer dat zorgaanbieders een aanvraag voor goedkeuring moeten indienen bij de Nederlandse Zorgautoriteit $(\mathrm{NZa})$ die in ieder geval inzicht biedt in het onderstaande (art. 49b Wmg):

a. de doelstellingen van de concentratie;

b. de redenen voor concentratie;

c. de structuur van de beoogde organisatie van de zorgaanbieder of zorgaanbieders;

d. de financiële gevolgen van de concentratie voor de zorgaanbieder of zorgaanbieders;

e. de gevolgen van de concentratie voor de zorgverlening aan de cliënt;

f. de risico's van de concentratie voor de kwaliteit en bereikbaarheid van de zorg en de wijze waarop deze risico's worden ondervangen;

g. het oordeel en de aanbevelingen van cliënten, personeel en andere betrokkenen over het voornemen tot concentratie en de wijze waarop zij dit kenbaar hebben kunnen maken, alsmede een onderbouwing voor de wijze waarop het oordeel of de aanbevelingen zijn meegewogen bij het voornemen tot concentratie; en

h. de wijze waarop en het tijdsbestek waarbinnen de concentratie zal worden gerealiseerd.

Om aan zorgaanbieders duidelijkheid te bieden over de eisen waaraan een aanvraag moet voldoen, inclusief de verplichte rapportage over de verwachte fusie-effecten (de zogeheten 'effectrapportage'), heeft de NZa een uitgebreide toelichting opgesteld. ${ }^{5}$ Deze omvangrijke toelichting is illustratief voor de administratieve lasten die de zorgspecifieke fusietoets met zich meebrengt. ${ }^{6}$ Dat hoeft op zich natuurlijk geen argument tegen de toets te zijn, mits op deze manier inderdaad ongewenste zorgfusies - zoals beoogd - worden voorkomen. En juist dat is twijfelachtig. Van meet af aan ligt de zorgspecifieke fusietoets onder vuur en wordt gewezen op het overbodige karakter ervan alsmede het dubbelwerk dat ermee bij zowel zorgaanbieders als toezichthouders wordt gecreëerd. ${ }^{7}$

3. In dit artikel wordt met 'fusie' iedere vorm van concentratie bedoeld zoals omschreven in de Mededingingswet.

4. Dit verbod is niet van toepassing op een zorgaanbieder die 'in de regel door minder dan vijftig personen zorg doet verlenen'.

5. NZa, Toelichting aanvraagformulier voorgenomen concentratie, Utrecht 2019.

6. In de MvT bij het wetsvoorstel worden de kosten van het opstellen van een effectrapportage en het indienen van een goedkeuringsverzoek voor zorgaanbieders geraamd op circa $€ 8.000$ (Kamerstukken II $2011 / 12,33253$, 3, p. 24). Hierbij wordt uitgegaan van ongeveer vier weken werk door 'een hoger opgeleide medewerker'. Op basis van de door de NZa opgestelde toelichting lijkt ons dit een zeer conservatieve inschatting, mede omdat zorgaanbieders in het kader van de zorgspecifieke fusietoets vaak gebruikmaken van ingehuurde juridische expertise.

7. Zie in navolging van Varkevisser \& Schut 2011 bijvoorbeeld ook D. Schrijvershof, 'Schaf de zorgspecifieke fusietoets af, focus het toezicht op de zorginkoop', Tijdschrift Zorg \& Recht in Praktijk 2014, nr. 6, p. $22-27$
Een belangrijke reden voor de twijfels ten aanzien van nut en noodzaak van de zorgspecifieke fusietoets is dat de toets van de NZa zuiver procedureel is. Er vindt geen beoordeling plaats of de beoogde fusie wel nuttig is. Ook wordt niet inhoudelijk ingegaan op de inbreng van clienten, personeel of andere betrokken. Anders dan de overheid in eerste instantie van plan was, bevat de zorgspecifieke fusietoets vanwege het ontbreken van toetsbare criteria terecht geen ex ante beoordeling door de zorgautoriteit van de effecten op de kwaliteit van de zorgverlening. Dit maakt dat de gedetailleerde effectrapportage die zorgaanbieders moeten opstellen in het gunstigste geval ervoor zorgt dat fusievoornemens inhoudelijk goed worden doordacht. Mede omdat aan fusies niet zelden strategische - lees: concurrentiebeperkende - overwegingen ten grondslag liggen, ${ }^{8}$ is dat echter lang niet vanzelfsprekend.

\section{Sterke groei aantal aanvragen}

Bij indiening van het wetsvoorstel is door de overheid de verwachting uitgesproken dat gemiddeld jaarlijks ongeveer 25 zorgfusies door de NZa zouden moeten worden beoordeeld. ${ }^{9}$ Zoals tabel 1 laat zien lag het aantal aanvragen in het eerste jaar na de invoering van de zorgspecifieke fusietoets al direct fors hoger. Sinds 2016 is bovendien sprake van een zeer sterke groei van het aantal goedkeuringsverzoeken.

Volgens opgave van de NZa zijn in het kader van de zorgspecifieke fusietoets het afgelopen jaar in totaal maar liefst 194 goedkeuringsverzoeken ingediend. ${ }^{10}$ Dat is bijna 30\% meer dan in 2017 en meer dan een verdubbeling ten opzichte van 2014. In de medisch-specialistische zorg is het aantal goedkeuringsbesluiten van 12 in 2014, na een tijdelijke daling in de jaren 2015 en 2016, gestegen tot 18 in 2017 en 29 in 2018.

Navraag bij de NZa heeft uitgewezen dat een aanvraag eigenlijk nooit wordt afgekeurd. Als een aanvraag in eerste instantie als onvoldoende wordt beoordeeld, dan krijgt de betreffende zorgaanbieder de gelegenheid deze aan te vullen totdat wel aan alle vereisten wordt voldaan. In een beperkt aantal gevallen werd gaandeweg dit (soms langdurige) proces een aanvraag tussentijds ingetrokken. Over de periode 2014 tot en met 2018 is dat in totaal 37 keer $(6 \%)$ voorgekomen. Kortom, uiteindelijk lukt het vrijwel iedereen om deze procedurele horde te nemen. Wel heeft de NZa recent voor de eerste keer gebruikgemaakt van haar bevoegdheid (op grond van art. 49c lid $3 \mathrm{Wmg}$ ) om voorwaarden aan de goedkeuring te verbinden. ${ }^{11}$ Dit betreft de overname van het IJsselland Ziekenhuis door het Erasmus MC. De zorgautoriteit heeft voor een deel van de zorginhoudelijke

8. J.P. Postma \& A.F. Roos, 'Why healthcare providers merge', Health Economics, Policy \& Law 2016, nr. 2, p. 121-140.

9. Kamerstukken // 2011/12, 33253, 3, p. 24.

10. Opvallend is dat, net als in 2017, een zeer groot deel van deze verzoeken betrekking heeft op de mondzorg. Dit hangt ongetwijfeld samen met de sterke groei van 'private equity' die met name in deze sector zichtbaar is; zie bijvoorbeeld het artikel 'Private equity mengt zich steeds meer in de zorg', NRC Handelsblad 13 maart 2019.

11. NZa, Concentratiebes/uit Erasmus Universitair Medisch Centrum Rotterdam - Stichting IJsselland Ziekenhuis, Utrecht 2019. 
Tabel 1 Aantal ingediende verzoeken en besluiten in het kader van de zorgspecifieke fusietoets

\begin{tabular}{lllllll}
\hline & 2014 & 2015 & 2016 & 2017 & 2018 & Totaal \\
\hline Aantal ingediende verzoeken & 87 & 84 & 135 & 151 & 194 & 651 \\
\hline Meldingen ingetrokken & 14 & 9 & 6 & 6 & 2 & 37 \\
\hline Aantal genomen besluiten & 55 & 90 & 113 & 126 & 165 & 549 \\
\hline w.v. 1e lijn, huisartsen, geboortezorg & $2 \%$ & $13 \%$ & $12 \%$ & $3 \%$ & $2 \%$ & $6 \%$ \\
\hline w.v. farmacie & $2 \%$ & $6 \%$ & $6 \%$ & $11 \%$ & $12 \%$ & $8 \%$ \\
\hline w.v. GGz & $24 \%$ & $21 \%$ & $20 \%$ & $9 \%$ & $7 \%$ & $14 \%$ \\
\hline w.v. langdurige zorg & $36 \%$ & $29 \%$ & $25 \%$ & $26 \%$ & $15 \%$ & $24 \%$ \\
\hline w.v. mondzorg & $15 \%$ & $14 \%$ & $26 \%$ & $34 \%$ & $48 \%$ & $32 \%$ \\
\hline w.v. revalidatiezorg, hulpmiddelen & $0 \%$ & $4 \%$ & $6 \%$ & $4 \%$ & $2 \%$ & $3 \%$ \\
\hline w.v. medisch specialistische zorg & $22 \%$ & $14 \%$ & $6 \%$ & $14 \%$ & $15 \%$ & $13 \%$
\end{tabular}

Bron: cijfers door de auteurs verkregen van de NZa.

samenwerking die beide ziekenhuizen voor ogen staat, vastgesteld dat de effectrapportage 'de gevolgen van de concentratie voor de zorgverlening aan cliënten en de risico's voor de kwaliteit en bereikbaarheid van de zorg niet volledig inzichtelijk maakt'. De ziekenhuizen moeten daarom - dat wil zeggen mits de fusie door de ACM wordt goedgekeurd en dus kan worden geëffectueerd gedurende een periode van vijf jaar jaarlijks schriftelijk aan de NZa rapporteren 'over de voortgang van de ontplooide zorginitiatieven', inclusief de risico's van de uitwerking van deze initiatieven voor de kwaliteit en bereikbaarheid van zorg.

\section{Terugblik: mededingingstoezicht op fusies zorgverzekeraars en ziekenhuizen}

Als zorgaanbieders de zuiver procedurele zorgspecifieke fusietoets met goed gevolg hebben doorlopen - en zij hun fusievoornemen willen effectueren - is het op grond van de Mededingingswet $(\mathrm{Mw})$ vervolgens aan de mededingingsautoriteit om te beoordelen of door de voorgenomen fusie een economische machtspositie ontstaat dan wel wordt versterkt. In het Nederlandse zorgstelsel met gereguleerde marktwerking is deze beoordeling cruciaal. In deze paragraaf laten we daarom aan de hand van een aantal belangrijke praktijkvoorbeelden zien welke ontwikkeling het fusietoezicht van eerst de Nederlandse Mededingingsautoriteit (NMa) en later de Autoriteit Consument \& Markt (ACM) sinds 2011 heeft doorgemaakt. Hierbij is er achtereenvolgens andacht voor fusies tussen zorgverzekeraars en ziekenhuizen.

\section{Zorgverzekeraars}

Op 1 juni 2011 heeft de NMa de fusie goedgekeurd tussen de zorgverzekeraars Achmea en De Friesland. ${ }^{12}$ Deze goedkeuring was bijzonder omdat het een fusie betrof van een verzekeraar met een zeer groot regionaal marktaandeel (De Friesland) en een verzekeraar met het grootste landelijke marktaandeel (Achmea) op een sterk geconcentreerde landelijke markt die bovendien de tweede speler was in de betreffende regio. Ondanks het hoge gezamenlijke marktaandeel in de provincie Friesland $(70-80 \%)$ was het naar het oordeel van de NMa niet aannemelijk dat Achmea en De Friesland na de fusie in staat zouden zijn om hun premie in deze regio significant te verhogen omdat beide zorgverzekeraars worden gedisciplineerd door de landelijke premies van de andere zorgverzekeraars. Net zo min achtte de NMa het aannemelijk dat de landelijke premies van de andere verzekeraars door de fusie zullen stijgen als gevolg van hogere inkoopprijzen in de provincie Friesland. Gesteld dat Achmea en De Friesland in staat zouden zijn om lagere inkoopprijzen af te dwingen bij de Friese zorgaanbieders (als gevolg waarvan hun concurrenten een hogere inkoopprijs zouden moeten betalen voor de zorg in Friesland), dan nog zou dat volgens de NMa (nagenoeg) geen effect hebben op hun landelijke premiestelling. De verzekerden in Friesland maken immers niet meer dan $2 \%$ uit van de totale verzekerdenpopulatie van de andere verzekeraars. Voorts concludeerde de NMa dat het, onder andere vanwege de wettelijke zorgplicht, ook niet annemelijk is dat de fusie zal leiden tot een verslechtering van de kwaliteit van het verzekerde pakket dan wel de ingekochte zorg. De goedkeuring van deze verzekeraarsfusie is destijds door ons stevig bekriti- 
seerd: 13 'De argumenten die de NMa aanvoert waarom de fusie niet tot hogere premies of een verslechtering van de kwaliteit zou leiden, zijn ontoereikend en soms zelfs onjuist. Bovendien zijn de dynamische effecten van de fusie op de marktstructuur volledig veronachtzaamd.' Deze kritiek heeft er mede toe geleid dat de mededingingsautoriteit als gevolg van een in 2013 door het toenmalige kabinet ingevoerde beleidsregel bij een volgende fusie van zorgverzekeraars in ieder geval specifiek aandacht dient te besteden aan (1) de verbinding tussen de polismarkt en de zorginkoopmarkt; (2) de mogelijkheden voor toetreding van zorgverzekeraars en de rol van kleine zorgverzekeraars; (3) de differentiatie van de polismarkt; en (4) coördinatie-effecten. ${ }^{14}$ Hoe dit in de praktijk uitpakt, is nog niet duidelijk, omdat op de sterk geconcentreerde Nederlandse zorgverzekeringsmarkt sindsdien geen nieuwe fusie is aangekondigd.

\section{Ziekenhuizen}

Gedurende de afgelopen decennia hebben tijdens een aantal opeenvolgende fusiegolven in Nederland meer dan 130 ziekenhuisfusies plaatsgevonden, waarvan bijna 25 in de periode vanaf $2010 .{ }^{15}$ Hoewel het behoud van voldoende keuzemogelijkheden essentieel is voor effectieve marktwerking in de Nederlandse ziekenhuissector zijn deze fusies op één na allemaal goedgekeurd. Bij een flink aantal fusies gebeurde dat op twijfelachtige gronden en is het licht in die gevallen te gemakkelijk op groen gezet. Hieronder bespreken we op hoofdlijnen de beoordelingen van drie spraakmakende ziekenhuisfusies, te weten die in Tilburg, Bergen op Zoom/Roosendaal en Dordrecht/Gorinchem. ${ }^{16}$

\section{- Ziekenhuisfusie Tilburg}

Op 2 november 2012 kregen het TweeSteden Ziekenhuis en het St. Elisabeth Ziekenhuis van de NMa toestemming om te fuseren. ${ }^{17}$ Beide ziekenhuizen bevinden zich in Tilburg en dus was de cruciale vraag of de ziekenhuizen in Breda, Eindhoven en 's-Hertogenbosch na de fusie voor voldoende concurrentiedruk zouden kunnen zorgen. De mededingingsautoriteit leek hier zelf niet van overtuigd:

'Op basis van patiëntenstromen concludeert de NMa dat partijen hoge gezamenlijke marktaandelen hebben en de concurrentiedruk van andere ziekenhuizen, die buiten het werkgebied van partijen gevestigd zijn, beperkt is. Daar komt bij dat er grote overlap is

13. E.M.H. Loozen, F.T. Schut \& M. Varkevisser, 'Fusie zorgverzekeraars Achmea en De Friesland: hoezo functioneel concentratietoezicht?', M\&M 2011/5, p. 169-177.

14. Zie art. 3 Beleidsregel concentraties van zorgaanbieders en zorgverzekeraars zoals die sinds 16 juli 2013 van toepassing is (https://wetten. overheid.nl/BWBR0033674/2013-07-16).

15. A.F Roos, F.T. Schut \& M. Varkevisser, 'Een halve eeuw ziekenhuisfusies in Nederland', ESB 2018, 103(4766), p. 440-443.

16. Vanwege het specifieke karakter ervan blijft de goedkeuring van de fusie tussen de Amsterdamse academische ziekenhuizen AMC en VUmc hier buiten beschouwing.

17. NMa, Besluit TweeSteden ziekenhuis - St. Elisabeth Ziekenhuis, Den Haag 2012 tussen de werkgebieden van partijen en de modellen van de NZa een hoog prijseffect voorspellen.'

Het gezamenlijke marktaandeel van $70-80 \%$ leidde echter toch niet tot een verbod omdat, zo stelde de toezichthouder mede op basis van de opvatting van de regionaal grootste zorgverzekeraar (CZ), de verzekeraars na de fusie 'mogelijk in staat kunnen zijn' om de ziekenhuizen te disciplineren door hun verzekerden in de richting van andere ziekenhuizen te sturen. De NMa erkende dat het omgekeerde 'evenzeer mogelijk' is en stemde daarom pas in met de fusie nadat met de betrokken ziekenhuizen een prijsplafond was afgesproken. Opvallend genoeg maakte dit prijsplafond formeel géén onderdeel uit van de goedkeuring. Er was slechts sprake van een 'side letter' waarvan de naleving, zo moest de NMa al snel toegeven, niet juridisch kon worden afgedwongen. Bovendien was het prijsplafond van tijdelijke aard, terwijl de fusie tot een structurele verandering van markt leidde. Dit goedkeuringsbesluit is eerder door ons getypeerd als hét voorbeeld van een falend mededingingstoezicht op ziekenhuisfusies. $^{18}$

\section{- Ziekenhuisfusie Bergen op Zoom/Roosendaal}

Ruim een half jaar na de goedkeuring van de Tilburgse ziekenhuisfusie kregen op 30 september 2013 ook het Lievensberg Ziekenhuis in Bergen op Zoom en het St. Franciscus Ziekenhuis in Roosendaal van de ACM groen licht voor hun fusieplannen. ${ }^{19}$ Kort samengevat is er ook in dit besluit van uitgegaan dat (1) de zorgverzekeraars in de toekomst meer op kwaliteit en prijs zullen sturen en (2) patiënten hen hierin dan zullen volgen. Dus voor zover de betreffende fusie überhaupt al tot meer marktmacht leidt, zal deze - zo concludeerde de mededingingsautoriteit - worden gecompenseerd door (toekomstige) disciplineringsmacht van de zorgverzekeraars. Het besluit was helaas exemplarisch voor de toetsingspraktijk van dat moment en werd door ons stevig bekritiseerd, met name omdat de ACM naar onze mening had nagelaten aan te tonen dat de ziekenhuisfusie niet tot significante marktmacht zou leiden. ${ }^{20}$ Mede op basis van onze argumentatie besloot de Nederlandse Patiënten Consumenten Federatie (NPCF), nu Patiëntenfederatie Nederland, om bezwaar aan te tekenen tegen dit goedkeuringsbesluit. Helaas bleef in deze zaak, toen het puntje na ongeveer anderhalf jaar bij het paaltje kwam, een inhoudelijke beoordeling van de toetsingspraktijk van de ACM door de rechter achterwege. De Rechtbank Rotterdam oordeelde op 9 april 2015 namelijk dat de NPCF

'niet is aan te merken als consumentenorganisatie als bedoeld in artikel 1 , onder $n$, van de Mededingingswet, zodat zij niet wordt geacht belanghebbende te

18. M. Varkevisser, E.M.H. Loozen \& F.T. Schut, 'Falend toezicht op ziekenhuisfusies brengt zorgstelsel in gevaar', Me Judice 3 december 2012.

19. ACM, Stichting Lievensberg Ziekenhuis - Stichting St. Franciscus Ziekenhuis, Den Haag 2013.

20. E.M.H. Loozen, M. Varkevisser \& F.T. Schut, 'Beoordeling ziekenhuisfusies door ACM: staat de consument wel echt centraal?', M\&M 2014/1, p. 5-14. 
zijn op de voet van artikel 93, eerste lid, van de Mw. $\mathrm{Nu}$ evenmin is gebleken dat eiseres belanghebbende is in de zin van artikel 1:2, derde lid, van de Awb, is haar beroep niet-ontvankelijk.' ${ }^{21}$

\section{- Ziekenhuisfusie Dordrecht/Gorinchem}

Die rechterlijke beoordeling is er niet heel lang daarna alsnog gekomen, zij het op een geheel andere wijze. Op 15 juli 2015 besloot de ACM namelijk om niet akkoord te gaan met de voorgenomen fusie van het Albert Schweitzer Ziekenhuis in Dordrecht en de Rivas Zorggroep in Gorinchem. ${ }^{22} \mathrm{Op}$ basis van de huidige patiëntenstromen en onderzoek onder huisartsen, patiënten en zorgverzekeraars concludeerde de mededingingsautoriteit dat beide ziekenhuizen belangrijke concurrenten van elkaar zijn. Deze keer waren het de beoogde fusieziekenhuizen die naar de rechter stapten. De uitspraak van de Rechtbank Rotterdam op 29 september 2016 betekende echter een belangrijke overwinning voor de ACM. ${ }^{23}$ De rechter oordeelde namelijk dat de ACM de conclusie om de fusie niet toe te staan heeft getrokken op basis van 'zorgvuldig verricht onderzoek'. De ACM had 'gemotiveerd toegelicht' dat een fusie tussen beide ziekenhuizen zou leiden tot 'achteruitgang in de disciplinering' door zorgverzekeraars, mede omdat het naar het oordeel van de rechtbank 'aannemelijk is dat patiënten die nu niet bewegen dat na de fusie ook niet zullen doen'. Dit laatste is ook voor toekomstige fusiebeoordelingen een belangrijke constatering omdat de relevante geografische markt - dat wil zeggen, het gebied waarbinnen de fuserende ziekenhuizen werkzaam zijn dus op basis van de huidige patiëntenstromen kan worden vastgesteld en niet op basis van speculaties over mogelijke, toekomstige veranderingen daarin, zoals in eerdere fusiebesluiten. Als gevolg hiervan zal dit gebied veelal beperkt van omvang blijken te zijn. Een fusie leidt dan sneller tot mededingingsproblemen. Van belang is ook dat de rechter de opvatting van de ACM deelde dat verzekeraars na de voorgenomen fusie 'niet over voldoende effectieve disciplineringsmogelijkheden beschikken'. Ook het argument van de ziekenhuizen dat de ACM in eerdere gevallen zelfs bij grotere gezamenlijke marktaandelen wél tot goedkeuring is overgegaan werd door de rechtbank van de tafel geveegd: 'In aanmerking nemende dat de ziekenhuissector een markt in transitie is en dat zorgverzekeraars in $2012 \mathrm{nog}$ niet beschikten over de ervaring die zij nu hebben, is verklaarbaar dat ACM nu tot een ander besluit is gekomen.'

\section{Voortschrijdend inzicht}

Ondanks de soms stevige kritiek op het toegeeflijke toezicht op ziekenhuisfusies heeft het tot 2015 geduurd alvorens de mededingingsautoriteit heeft durven doorbijten. Het verbodsbesluit inzake de voorgenomen fusie van de ziekenhuizen in Dordrecht en Gorinchem en de uiteindelijke rechterlijke uitspraak heeft laten zien dat

22. ACM, Stichting Albert Schweitzer Ziekenhuis - Stichting Rivas Zorggroep, Den Haag 2015.

23. ECLI:NL:RBROT:2016:7373. de ACM bij de beoordeling van ziekenhuisfusies in beginsel over voldoende (juridische) slagkracht beschikt. Mede omdat de zorgverzekeraars hebben aangeven vaker inkoopproblemen te ervaren als gevolg van fusies heeft de ACM eind 2017 laten weten de aandacht voor concurrentierisico's van ziekenhuisfusies te verscherpen. ${ }^{24}$ Onderzoek naar de effecten van ziekenhuisfusies - op basis waarvan werd geconstateerd dat fusies veelal tot hogere prijzen hebben geleid zonder aantoonbare verbetering van de kwaliteit van zorg - heeft hier ook in belangrijke mate aan bijgedragen. ${ }^{25}, 26$ Ook heeft de ACM laten weten dat fuserende ziekenhuizen (en zelfstandige behandelcentra) voortaan per patiëntengroep moeten beschrijven welke keuzemogelijkheden er overblijven voor zorgverzekeraars en verzekerden om voor verschillende zorgvormen beter te kunnen beoordelen wat de gevolgen zijn van de fusie. ${ }^{27}$

\section{Vooruitblik: hoe nu verder?}

\section{AMM-instrument}

Als gevolg van het grote aantal ziekenhuisfusies is de concentratiegraad in de Nederlandse ziekenhuismarkt de afgelopen halve eeuw zo sterk toegenomen dat de vraag zich opdringt of scherper fusietoezicht nog veel zoden aan de dijk zal zetten. In veel regio's lijkt het kalf al verdronken. ${ }^{28}$ Wanneer sprake blijkt te zijn van problematische machtsposities, dan dienen deze via het instrument van aanmerkelijke marktmacht te worden ingekapseld. Met dit zogeheten wettelijke AMM-instrument (artikel $48 \mathrm{Wmg}$ ) kunnen specifieke verplichtingen worden opgelegd aan zorgpartijen met veel marktmacht. Hoe effectief dit instrument in de praktijk is, is tot op zekere hoogte echter nog onduidelijk. Tot op heden heeft de NZa hiervan namelijk slechts in twee bijzondere situaties gebruikgemaakt. De eerste keer in 2011 toen aan de enige apotheker in Breskens de verplichting werd opgelegd om een contract met zorgverzekeraar Menzis te tekenen en de tweede keer in 2012 toen samenwerkingsverbanden van huisartsen in Almere en Prinsenbeek de verplichting kregen opgelegd om patiënten naar de door hen zelfgekozen (internet)apotheek door te verwijzen. Wellicht dat de effectiviteit van het AMM-instrument kan worden verhoogd door de voorgenomen maatregelen om de toepassing hiervan onder te brengen bij de ACM in combinatie met (1) het schrappen van de expliciete verplichting om eerst te komen tot een 'volgens de beginselen van het algemeen

24. ACM, Verscherpte aandacht voor concurrentierisico's ziekenhuisfusies: toelichting, Den Haag 2017.

25. ACM, Prijs- en volume-effecten van ziekenhuisfusies: onderzoek naar effecten van ziekenhuisfusies 2007-2014, Den Haag 2017.

26. Significant, Ziekenhuisfusies en kwaliteit van zorg: onderzoek naar de effecten van ziekenhuisfusies op de kwaliteit van zorg, Barneveld 2016.

27. ACM, Analyse van productmarkt(en) in de medisch-specialistische zorg: werkwijze, Den Haag 2018.

28. M. Varkevisser \& F.T. Schut, 'Hospital merger control in the Netherlands: was the barn closed in time or has the horse already bolted?', CPI Antitrust Chronicle juli 2017, p. 56-59. 
mededingingsrecht afgebakende markt' en (2) het aanreiken van enkele aanvullende verplichtingen die kunnen worden opgelegd. ${ }^{29}$ Los van het feit dat deze voorgestelde wijzigingen op dit moment nog niet door de Tweede Kamer zijn aangenomen, blijft dit zonder daadwerkelijke toepassing en relevante jurisprudentie voorlopig echter speculeren.

\section{Aanscherping fusietoezicht}

In aanvulling op ingrijpen achteraf blijft het daarnaast van groot belang om iedere nieuwe zorgfusie streng te beoordelen. De eveneens beoogde overheveling van de zorgspecifieke fusietoets van de NZa naar de ACM dient hieraan een bijdrage te gaan leveren. ${ }^{30}$ Dit lijkt gezien de hiervoor uiteengezette tekortkomingen van deze toets echter onwaarschijnlijk. Weliswaar komt het gehele toezicht op zorgfusies straks in één hand - wat de duidelijkheid vergroot en de kans op dubbelwerk verkleint - maar het is nog onduidelijk welke inhoudelijke aanscherpingen precies zijn voorzien. Het ingediende wetsvoorstel creëert de mogelijkheid 'om fusies in het kader van de zorgspecifieke fusietoets te laten toetsen op nadere bij ministeriële regeling te bepalen eisen'. Op verzoek van de minister van VWS heeft de ACM, samen met de NZa en de Inspectie Gezondheidszorg en Jeugd (IGJ), drie beleidssuggesties gedaan voor de invulling van zo'n ministeriële regeling. Kort samengevat heeft de mededingingsautoriteit drie opties, inclusief hun voor- en nadelen, aangedragen gericht op (het voorkomen van) schaalgrootte en machtsposities: ${ }^{31}$

1. Fusies waarbij een van de zorgaanbieders over een machtspositie beschikt, zijn in bepaalde situaties en bepaalde zorgsectoren sowieso verboden, tenzij hier substantiële voordelen tegenover staan.

2. Voor zorgaanbieders met een machtspositie wordt het verplicht om delen van zorg af te stoten als dit vanuit een kosten- en toegankelijkheidsperspectief wenselijk is.

3. Fusies boven een bepaalde schaalgrootte zijn verboden, tenzij hier substantiële voordelen tegenover staan.

De eerste optie makt het in theorie bijvoorbeeld mogelijk om fusies tussen ziekenhuizen die in een andere geografische markt opereren - waardoor de fusie in principe geen gevolgen kan hebben voor de keuzemogelijkheden voor patiënten of de inkoop door zorgverzekeraars toch te verbieden. Dit kan bijvoorbeeld van belang zijn als sprake is van marktoverstijgende afhankelijkheden, zoals hierna nader zal worden toegelicht. In een recente brief aan de Tweede Kamer, waarin het belang van een scherp toezicht op zorgfusies wordt benadrukt, heeft de minister van VWS laten weten alleen de 'potentiële meerwaarde' van deze eerste optie te zien. ${ }^{32}$ Het is dan ook de bedoeling dat deze suggestie verder wordt uitge-

29. Kamerstukken II 2015/16, 34445, 3.

30. Kamerstukken I/ 2015/16, 34445, 3.

31. ACM, Reactie ACM op verzoeken Minister om suggesties voor verscherping fusietoezicht, Den Haag 2018.

32. Kamerstukken II 2018/19, 34445, 13. werkt om 'de wenselijkheid en haalbaarheid' ervan beter te kunnen beoordelen. De tweede optie acht het kabinet niet proportioneel omdat dit te ver zou ingrijpen in de ondernemingsvrijheid van zorgaanbieders. De huidige Mw biedt de ACM overigens al de mogelijkheid om in het geval van mededingingsbezwaren structurele remedies op te leggen. Bij een aantal zorgfusies is van deze mogelijkheid ook gebruikgemaakt. ${ }^{33}$ Het kabinet is evenmin voorstander van de derde optie. Die legt naar zijn opvatting te veel nadruk op de schaalgrootte en houdt te weinig rekening met de complexiteit en dynamiek van het zorgaanbod.

\section{Belangrijke aandachtspunten}

Met de minister delen wij het inzicht dat een scherp toezicht op zorgfusies van groot belang is. Wij zijn daarbij van mening dat het bestaande wettelijk instrumentarium hiervoor in principe geschikt en toereikend is. ${ }^{34}$ Dat wil zeggen, mits ook bij zorgfusies de algemeen geldende regels van de Mw door de ACM voldoende strikt worden toegepast. De mededingingsautoriteit lijkt dit ook van plan. Niettemin zijn er wel degelijk enkele belangrijke aandachtspunten voor het toekomstige mededingingstoezicht. ${ }^{35}$

Ten eerste is het, in aanvulling op beter fusietoezicht vooraf, van groot belang om achteraf scherper toezicht te gaan houden op misbruik van marktmacht door reeds gefuseerde ziekenhuizen. Meer empirisch onderzoek op dit gebied is dringend gewenst. Door achteraf de effecten van ziekenhuisfusies goed te onderzoeken kan niet alleen streng worden opgetreden als dat nodig is, maar ook ontstaan inzichten die gebruikt kunnen worden om het fusietoezicht vooraf te verbeteren. Zo blijkt uit onderzoek dat bij de beoordeling van ziekenhuisfusies meer aandacht nodig is voor het definiëren van productmarkten, de potentiële verschillen tussen de afzonderlijke locaties van een fusieziekenhuis en de rol van verzekeraars. ${ }^{36}$ Ook de verdere verbetering van fusiesimulatiemodellen kan een bijdrage leveren aan de benodigde aanscherping van het preventieve toezicht op ziekenhuisfusies. ${ }^{37}$ De aandacht dient daarbij dan vooral uit te gaan naar regio's die al sterk geconcentreerd zijn geraakt. Overigens blijkt uit recent Amerikaans onder-

33. De overname van Mediq door Brocacef is in 2016 door de ACM goedgekeurd onder de voorwaarde dat Brocacef een aantal apotheken zou verkopen, omdat de nieuwe apotheekketen in bepaalde gemeenten anders te machtig zou worden. Om dezelfde reden heeft de ACM in 2017 aan haar instemming met de fusie van de GGZ-aanbieders Parnassia en Antes de voorwaarde verbonden dat bepaalde klinieken, behandelcentra en patiënten moeten worden afstoten.

34. Zie ook E.M.H. Loozen, Wijziging regelgeving markttoezicht in de zorg, onderzoeksrapport 2015.05, ESHPM/Erasmus Universiteit Rotterdam.

35. Zie ook M. Varkevisser, Hand in hand: op zoek naar de juiste balans tussen marktwerking en overheidsingrijpen in de gezondheidszorg (oratie Rotterdam), Erasmus Universiteit Rotterdam 2019.

36. A.F. Roos, R.R. Croes, V. Shestalova, M. Varkevisser \& F.T. Schut, 'Price effects of a hospital merger: heterogeneity across health insurers, hospital products and hospital locations', Health Economics 2019 (te verschijnen).

37. R.R. Croes \& A.F. Roos, 'Back to the future: predictive power of the option demand method in the Dutch hospital industry', in: R.R. Croes, Market power in hospital markets and selection in health insurance markets (diss. Rotterdam), Erasmus Universiteit Rotterdam 2019. 
zoek dat fusies tussen ziekenhuizen uit verschillende regio's eveneens tot aanzienlijke prijsstijgingen kunnen leiden. ${ }^{38}$ Dit duidt erop dat wanneer ziekenhuizen geen directe concurrenten van elkaar zijn, een fusie hun onderhandelingspositie ten opzichte van de zorgverzekeraars toch kan versterken. Dit kan verschillende redenen hebben. Zo heeft een ziekenhuis wellicht meer marktmacht wanneer het als één organisatie in meerdere regio's actief is die tot het (kern)werkgebied van een zorgverzekeraar behoren. Het is ook mogelijk dat door de krachtenbundeling aan de kant van het gefuseerde ziekenhuis een capabeler onderhandelingsteam ontstaat en/of geprofiteerd kan worden van extra informatie over contractonderhandelingen met verzekeraars in andere regio's, waarbij de regio met de voor het ziekenhuis gunstigste uitkomst als referentiepunt kan dienen. De mogelijkheid van deze zogeheten cross-market dependencies kan belangrijke gevolgen hebben voor het mededingingstoezicht op ziekenhuisfusies en vraagt dus om verder onderzoek. Wanneer dergelijke marktoverstijgende afhankelijkheden inderdaad de mededinging in (een van) de betrokken markten kan beperken, biedt de door de ACM voorgestelde optie om fusies waarbij een van de betrokken partijen reeds een machtspositie heeft, sowieso te verbieden een mogelijkheid om dit risico op voorhand te beperken.

Ten tweede bestaat een grote behoefte aan onderzoek naar de complexe relatie tussen volumenormen, concurrentie en kwaliteit. Momenteel vormt de concentratie van hoogcomplexe zorg - zoals bepaalde kankeroperaties - een belangrijke reden voor ziekenhuisfusies, hoewel dit tot op heden door ziekenhuizen niet formeel als 'efficiëntieverweer' voor voorgenomen fusies is aangevoerd. Op die manier kan immers worden voldaan aan de minimumvolumenormen. Zowel in Nederland ${ }^{39}$ als in andere landen ${ }^{40}$ worden deze normen steeds verder opgeschroefd vanuit de gedachte dat het behandelen van een bepaald minimumaantal patiënten belangrijk is om een goede kwaliteit te kunnen garanderen. Vanuit marktordeningsperspectief is het echter de vraag of het wenselijk is om deze concentratie te laten plaatsvinden via ziekenhuisfusies of door concentratie van uitsluitend de betreffende vormen van hoogcomplexe zorg in een beperkt aantal ziekenhuizen (en dus het afstoten van deze vormen van zorg door andere ziekenhuizen). Indien nut en noodzaak hiervan afdoende worden aangetoond, lijkt het faciliteren en toestaan van marktverdelingsafspraken ten aanzien van dergelijke hoogcomplexe zorg verstandiger dan het toestaan van fusies omdat bij een fusie ook de concurrentie op alle overige vormen van ziekenhuiszorg wordt gereduceerd. Voor een goede

38. M.S. Lewis \& K.E. Pflum, 'Hospital systems and bargaining power: evidence from out-of-market acquisitions', RAND Journal of Economics 2017, nr. 3, p. 579-610.

39. R. Mesman, M.J. Faber, B.J.J.M. Berden \& G.P. Westert, 'Evaluation of minimum volume standards for surgery in the Netherlands (20032017): a successful policy?', Health Policy 2017, nr. 12, p. 1263-1273.

40. J. Morche, D. Renner, B. Pietsch, L. Kaiser, J. Brönneke, S. Gruber \& K. Matthias, 'International comparison of minimum volume standards for hospitals', Health Policy 2018, nr. 11, p. 1165-1176. beoordeling van dergelijke afspraken dient de ACM dan wel vanuit het patiëntperspectief een integrale afweging te maken. ${ }^{41}$ Alleen zo kan duidelijk worden of de kwaliteitsvoordelen van concentratie in voldoende mate opwegen tegen de potentiële nadelen ervan, in de vorm van extra reistijd ${ }^{42}$ en minder concurrentie tussen ziekenhuizen onderling. ${ }^{43}$

\section{Conclusie}

Sinds ons vorige artikel in dit tijdschrift in 2011 is de concentratie in de Nederlandse gezondheidszorg, en de ziekenhuissector in het bijzonder, toe- in plaats van afgenomen. Terugblikkend kunnen we constateren dat de invoering van de zorgspecifieke fusietoets in 2014 de reeds eerder ingezette tendens niet heeft kunnen keren. De honderden voorgenomen zorgfusies die sindsdien door de NZa zijn beoordeeld, ${ }^{44}$ zijn nagenoeg zonder uitzondering goedgekeurd. Hoewel de fusietoets kan hebben bijgedragen aan inhoudelijk beter doordachte fusies, is het de vraag of dit potentiële voordeel opweegt tegen de enorme extra administratieve belasting. In elk geval heeft deze zuiver procedurele toets de schaalvergroting in de zorg niet merkbaar kunnen afremmen. Mogelijk zou de voorgenomen overheveling van de fusietoets naar de ACM in combinatie met een uitbreiding van het instrumentarium om bepaalde fusies tegen te houden meer effect kunnen sorteren. Maar een grondige evaluatie van nut en noodzaak van de zorgspecifieke fusietoets lijkt op zijn plaats.

Voor het voorkomen van machtsposities lijkt de zorgspecifieke fusietoets in elk geval overbodig, omdat het bestaande wettelijke instrumentarium hiervoor in principe al geschikt en toereikend is. Het probleem zit dan ook niet zozeer in het wettelijke instrumentarium zelf, maar in de toepassing daarvan. Zoals hiervoor in onze terugblik beargumenteerd, heeft de ACM tot op heden ten onrechte vrijwel alle ziekenhuisfusies goedgekeurd. Gelukkig lijkt er sinds 2015 sprake van een kentering in deze lankmoedige houding van de mededingingsautoriteit. Deze verandering is mede ingegeven door de resultaten van empirisch onderzoek naar de effecten van ziekenhuisfusies en de ervaringen van zorgverzekeraars met sterke machtposities van fusieziekenhuizen. Het is helaas de vraag of deze kentering nog op tijd komt. In veel regio's is de ziekenhuismarkt reeds zo sterk gecon-

41. W. van der Schors, R. Kemp \& M. Varkevisser, Collaboration and competition policy in a market-based hospital system: a case-study from The Netherlands (artikel ingediend voor publicatie).

42. S.E. Versteeg, V.K.Y. Ho, S. Siesling \& M. Varkevisser, 'Centralisation of cancer surgery and the impact on patients' travel burden', Health Policy 2018, nr. 9, p. 1028-1034

43. V. Ho, R.J. Town \& M.J. Heslin, 'Regionalization versus competition in complex cancer surgery', Health Economics, Policy and Law 2007, nr. 1, p. 51-71.

44. Het voornemen om twee drempelbedragen te gaan hanteren zal naar verwachting leiden tot een vermindering van het aantal aanvragen. Zeer kleine transacties, bijvoorbeeld als een eenmanspraktijk wordt overgenomen, zijn dan van de zorgspecifieke fusietoezicht uitgezonderd; zie Kamerstukken I/ 2015/16, 34445, 3. 
centreerd dat er maar weinig ruimte voor effectieve concurrentie is overgebleven. Desalniettemin geldt natuurlijk ook hier: beter ten halve gekeerd dan ten hele gedwaald. Dus moeten de argumenten voor nieuwe fusies - bijvoorbeeld om te komen tot verdere concentratie van hoogcomplexe zorg - uiterst kritisch worden gewogen en worden afgezet tegen minder concurrentiebeperkende alternatieven. Ten slotte vereist de toegenomen marktconcentratie in de zorgsector een versterking van het toezicht gericht op het tegengaan van misbruik van marktmacht. Dit is temeer van belang omdat in Nederland een eenmaal voltrokken ziekenhuisfusie wettelijk niet meer terug te draaien valt. Daarnaast zal een dergelijke ontvlechting in de praktijk veelal onwenselijk zijn vanwege hoge kosten en schadelijke effecten voor de patiëntenzorg. Om de voormalige minister van VWS Edith Schippers te citeren toen zij tijdens een algemeen overleg werd gevraagd de fusie van de ziekenhuizen in Goes en Vlissingen bij gebrek aan resultaat weer ongedaan te maken: 'Ik kan de fusie niet terugdraaien. Dat heb je met eieren die je klutst. Die kun je niet meer terugpakken uit de pan. Dat is meestal een tamelijk dramatische exercitie. ${ }^{45}$ In 2007 werd om die reden, na een hoger beroep van het gefuseerde ziekenhuis, door de Amerikaanse mededingingsautoriteit uiteindelijk afgezien van het achteraf opsplitsen van een concurrentiebeperkende ziekenhuisfusie en kwam hiervoor een gedragsremedie in de plaats. ${ }^{46}$

In vergelijking met 2011 is als gevolg van de steeds verdergaande concentratie in de zorg de consensus gegroeid dat een scherp toezicht op fusies en machtsposities in de zorg noodzakelijk is. Hopelijk vertaalt zich dit de komende jaren blijvend in een effectiever mededingingstoezicht. De juiste beweging lijkt ingezet, maar 'the proof of the pudding' is natuurlijk ook nu 'in the eating'. 